\title{
Cardiac metastasis of oral squamous cell carcinoma
}

\author{
Neeraj Pattni, ${ }_{1}^{1}$ Andrew Rennie, ${ }^{1}$ Timothy Hall, ${ }^{1}$ Aidan Norman ${ }^{2}$
}

${ }^{1}$ Department of Oral and Maxillofacial Surgery, Worcester Royal Hospital, Worcester, UK

${ }^{2}$ Worcester Royal Hospital, Worcester, UK

\section{Correspondence to}

Neeraj Pattni,

neeraj.pattni@googlemail.com

Accepted 28 August 2015
CrossMark

To cite: Pattni N, Rennie A,
Hall T, et al. BMJ Case Rep
Published online: [please
include Day Month Year]
doi:10.1136/bcr-2015-
211275

To cite: Pattni N, Rennie A, Hall T, et al. BMJ Case Rep Published online: [please 211275

\section{SUMMARY}

We present a case of isolated cardiac metastasis of oral squamous cell carcinoma. An 89-year-old woman was due to undergo curative resection of a histologically proven squamous cell carcinoma of the retromolar region. On admission, it was noted that there were ECG changes, and following further investigations, the patient was diagnosed with a cardiac metastasis of her oral malignancy. The presentation, including the diagnostic difficulties, as well as the clinical features of this rare case, are discussed.

\section{BACKGROUND}

Squamous cell carcinoma (SCC) of the oral cavity accounts for $2 \%$ of all new cancers in the UK. ${ }^{1}$ Metastatic spread typically occurs to locoregional lymph nodes. The incidence of distant metastasis is low, but when this does occur, several organ systems account for the majority of cases. Isolated cardiac metastasis of oral SCC is rare. It is important to acknowledge how cardiac metastasis may present in an acute setting to ensure patients are managed appropriately.

\section{CASE PRESENTATION}

An 89-year-old woman, otherwise fit and well, presented with a lesion in the oral cavity. Following further investigations, this was diagnosed as a T4N2M0 SCC of the left retromolar region. The patient was offered curative surgery but initially declined. She began radiotherapy but soon elected to pursue surgery with curative intent. A staging CT scan was undertaken, which showed no distant metastasis of her oral malignancy.

The patient was admitted a day prior to her procedure. Routine observations undertaken showed tachycardia, with a rate of approximately 140$160 \mathrm{bpm}$. On questioning, she denied chest pain or dyspnoea. On examination, she was haemodynamically stable but an irregularly irregular pulse with no murmurs or added heart sounds was noted. A bedside ECG was performed, which showed ST-segment elevation suggesting an acute myocardial infarction. On further questioning, the patient did admit to a sensation of central chest 'heaviness' over the preceding 2 weeks. A cardiology opinion was sought. The patient was prescribed $2.5 \mathrm{mg}$ bisoprolol, following which her rate and rhythm were restored, although ECG changes were still apparent and serial troponin levels were elevated. Her procedure was postponed pending further investigation. A transthoracic echocardiogram was arranged, which showed a mass at the apex of the right ventricle, almost extending to the tricuspid valve (figure 1). Subsequently, the patient underwent a CT of the thorax, which showed a large necrotic soft tissue mass that appeared to be arising within the pericardium and invading into the right ventricle (figure 2).

These findings were consistent with cardiac metastasis of an oral SCC. The patient was deemed unsuitable for curative surgery and was managed palliatively at home. She died approximately 1 month later.

\section{DISCUSSION}

Distant metastasis of oral SCC is seen in $4.2-23.8 \%$ of patients. ${ }^{2}$ The most common sites are the lung, bone and liver. Cardiac metastases are most often seen with breast, lung and haematological malignancies. ${ }^{3}$ Cardiac metastasis of oral SCC is rare; only five other living cases have been reported. ${ }^{3-6}$ However, when considering autopsy studies, the prevalence of cardiac metastasis is higher. Gassman $\mathrm{et} \mathrm{al}^{7}$ reported two cases (1.5\%) among 126 patients with SCC of the tongue, whereas Majonlovic reported nine cases (24\%). ${ }^{8}$ The higher prevalence may be due to widespread dissemination of a malignancy, as opposed to an isolated cardiac metastasis.

Metastasis to the heart may occur in several different ways, including through direct extension, via the bloodstream or via the lymphatic system, or by intracavitary diffusion via the inferior vena cava or pulmonary veins. ${ }^{9}$ It is likely that spread in our patient was via the latter means due to its location in the right ventricle. In widespread disseminated malignancy, the earlier mechanism may play a more prominent role.

Clinical findings in those with cardiac metastasis are non-specific. ${ }^{3}$ In the early stages, patients may be asymptomatic, whereas later on they may present with conduction abnormalities, valvular

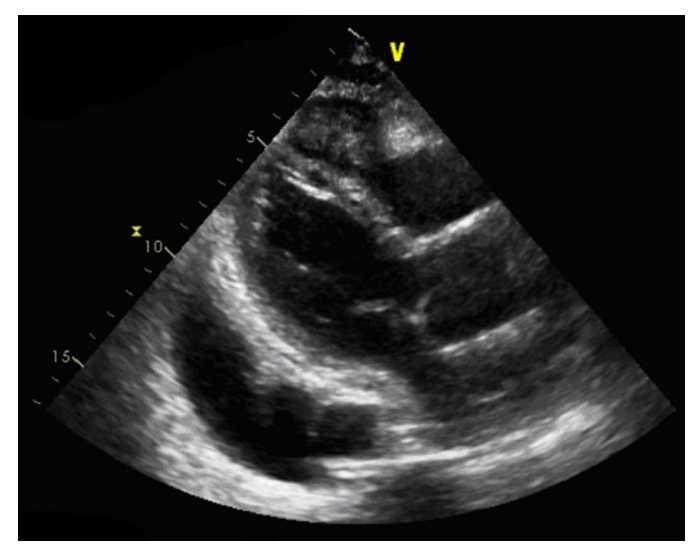

Figure 1 Transthoracic ECHO demonstrating mass at the right ventricle. 
Figure 2 CT scan demonstrating necrotic cardiac mass (right) compared to staging $\mathrm{CT}$ taken approximately 6 months earlier (left).
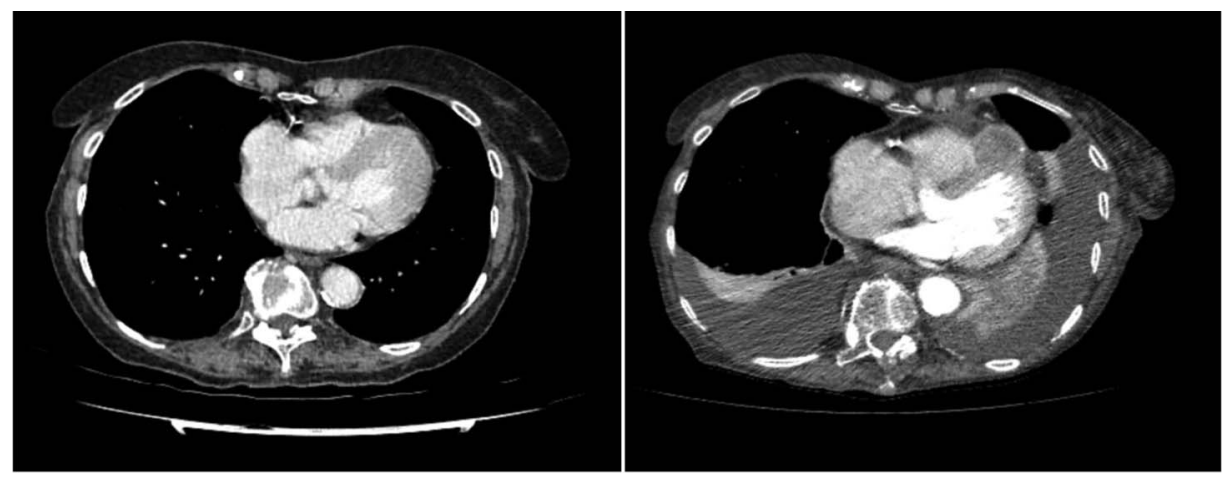

disease, angina, tamponade or cardiac failure. ECG features, if present, are also non-specific and include ST elevation, atrial fibrillation, right bundle branch block and pathological Q-waves. In our patient, the ECG findings were not indicative of a specific cardiac pathology. Initially, the patient was managed for paroxysmal atrial fibrillation, although the ECG changes were not characteristic of this. The ST segment and T-wave changes may be seen in acute coronary syndrome, but the lack of clinical symptoms and absence of troponin changes made this unlikely. Owing to the ECG findings observed in our case, further investigations, principally radiological, would be required. A mass lesion on the myocardium and/or pericardium will, in most cases, be diagnostic. Echocardiogram characteristics have been described as 'salmon roe' lesions, ${ }^{10}$ however, these were not seen in our patient. Further investigations are not normally required. Although histology remains the gold standard diagnostic tool, its applicability in patients with cardiac metastatic is limited as it offers no further benefit.

Once diagnosed, treatment is palliative, with radiotherapy and/or chemotherapy being advocated in limited cases.

\section{Learning points}

- Cardiac metastasis of oral squamous cell carcinoma (SCC) is rare.

- For those with a primary oral SCC presenting with atypical chest pain or non-specific ECG changes, cardiac metastasis should be considered in the differential diagnosis.

- Distant metastasis of oral SCC carries a poor prognosis and patients should be staged correctly to ensure they are managed appropriately.
Nevertheless, cardiac surgery has also been used to avoid an acute cardiac event; however, this patient died 4 weeks subsequently; ${ }^{3}$ the effect of palliative cardiac surgery on prognosis is unclear.

Contributors NP and AR prepared the manuscript. TH and AN reviewed and amended the manuscript.

Competing interests None declared.

Patient consent Obtained.

Provenance and peer review Not commissioned; externally peer reviewed.

\section{REFERENCES}

1 Data were provided by the Office for National Statistics on request, July 2013 Similar data can be found here: http://www.ons.gov.uk/ons/rel/vsob1/ cancer-statistics-registrations--england--series-mb1-/index.html

2 Ferlito $A$, Shaha AR, Silver CE, et al. Incidence and sites of distant metastases from head and neck cancer. ORL J Otorhinolaryngol Relat Spec 2001;63:202-7.

3 Nagata S, Ota K, Nagata M, et al. Cardiac metastasis of head and neck squamous cell carcinoma. Int J Oral Maxillofac Surg 2012;41:1458-62.

4 Werbel GB, Skom JH, Mehlman D, et al. Metastatic squamous cell carcinoma to the heart. Unusual cause of angina decubitus and cardiac murmur. Chest 1985;88:468-9

5 Rivkin A, Meara JG, Li KK, et al. Squamous cell metastasis from the tongue to the myocardium presenting as pericardial effusion. Otolaryngol Head Neck Surg 1999;120:593-5.

6 Schwender FT, Wollner I, Kunju LP, et al. Squamous cell carcinoma of the buccal mucosa with metastases to the pericardial cavity, lung and thyroid. Oral Oncol 2002:38:114-16

7 Gassman HS, Meadows R Jr, Baker LA. Metastatic tumors of the heart. Am J Med 1955; 19:357-65

8 Manojlović S. Metastatic carcinomas involving the heart. Review of postmortem examination. Zentralb/ Allg Pathol 1990;136:657-61.

9 Bussani R, De-Giorgio F, Abbate A, et al. Cardiac metastasis. J Clin Pathol 2007;60:27-34.

10 Chen HC, Lee WC, Chua S. Biventricular 'salmon roe' lesions: intracardiac metastasis from oral squamous cell carcinoma. Eur Heart J Cardiovasc Imaging 2014;15:835.

Copyright 2015 BMJ Publishing Group. All rights reserved. For permission to reuse any of this content visit

http://group.bmj.com/group/rights-licensing/permissions.

BMJ Case Report Fellows may re-use this article for personal use and teaching without any further permission.

Become a Fellow of BMJ Case Reports today and you can:

- Submit as many cases as you like

- Enjoy fast sympathetic peer review and rapid publication of accepted articles

- Access all the published articles

- Re-use any of the published material for personal use and teaching without further permission

For information on Institutional Fellowships contact consortiasales@bmjgroup.com

Visit casereports.bmj.com for more articles like this and to become a Fellow 